\title{
Response of Drip Fertigation, Intra Row Seeding of Legume and Planting Geometry on Water Use and Yield of Summer Maize
}

\author{
Minu Mohan*, A.L. Rathore and S.K. Jha \\ Department of Agronomy, College of Agriculture, Raipur, Indira Gandhi Krishi \\ Visvavidyalay, Raipur Chhattisgarh, India \\ *Corresponding author
}

\section{A B S T R A C T}

\section{Keywords}

Drip fertigation, Planting geometry, Recommended Fertilizer Doze (RDF)

Article Info

Accepted: 06 September 2018 Available Online: 10 October 2018
Field experiment was conducted on Research farm, Indira Gandhi Krishi Vishvavidyalaya Raipur during summer 2016 to study the response of drip fertigation intra row seeding of legume and planting geometry on soil health productivity and net return of summer maize. The experiment was laid in strip plot design with six vertical drip fertigation and intra row cowpea and three horizontal planting geometry with eighteen treatments. Six fertigation and intra row cowpea treatments include (F1) Drip fertigation 100\% RDF, (F2) Drip fertigation 125\%RDF, (F3) Surface irrigation (furrow) 100\%RDF, (F4) Drip fertigation $100 \% \mathrm{RDF}+$ intra row cowpea (F5) Drip fertigation $125 \% \mathrm{RDF}+$ intra row cowpea (F6) Surface irrigation (furrow) $100 \% \mathrm{RDF}+$ intra row cowpea and three horizontal treatments include (S1) $30 \times 20 \mathrm{~cm}$, (S2) $45 \times 20 \mathrm{~cm}$, (S3) $60 \times 20 \mathrm{~cm}$. Highest water use efficiency was found in drip fertigation $125 \% \mathrm{RDF}+$ intra row cowpea which was comparable with drip fertigation $100 \%$ RDF + cowpea and drip fertigation $100 \%$ RDF.

\section{Introduction}

Water is the vital source for crop production and is the most limiting factor in Indian agricultural scenario. Though, India has the largest irrigation network, the irrigation efficiency has not been achieved more than 40 per cent. Due to water scarcity, the available water resources should be very effectively utilized through water saving irrigation technologies. As water is a vital natural resource available on the earth, it is in constant demand for domestic use, animal husbandry and agriculture as well as industrial consumption. A major quantity of water is utilized in agriculture sector, however utilizable water resources in India are not enough to irrigate the entire cultivable area. Losses of water and nutrient through leaching and surface runoff, water logging and salinity effect are the disadvantages associated with conventional irrigation methods. Hence, concerted efforts are needed to minimize the use of this precious water. Water scarcity is an increasingly important issue of the whole world. The world climate change impact leading to increasing temperature and decreasing rainfall will lead to water scarcity even more. The pressure for the most efficient use of water for agriculture is intensifying with the increased competition for water resources among various sectors with 
mushrooming population. In spite of having the largest irrigated area in the world, India too has started facing severe water scarcity in different regions. Drip irrigation allows precise timing and uniform distribution of fertilizer nutrients. Maize is one of the amenable crops for drip irrigation system, which is an efficient system of irrigation (Zhu et al., 2007). By definition, fertigation is the precise application of water soluble fertilizer through sprinkler and drip irrigation. It is an efficient and agronomical sound method of providing soluble plant nutrients directly to the active plant root zone. Drip irrigation with fertigation offers a vast potential for optimum utilization of water and fertilizers (Raina et al.,; 1999). Research work on drip irrigation conducted so far in India and abroad proved that this method lead not only to appreciable saving of water, but also results in achieving higher crop yields as compare to surface irrigation method. Besides, this drip irrigation has quite a large number of beneficial aspects such as maximum production per unit of water, improvement on quality of produce, less evaporation losses, uniform water distribution, easy operation and suitable for all type of soils.

\section{Materials and Methods}

Field experiment was conducted on Research farm, Indira Gandhi Krishi Vishvavidyalaya Raipur during summer 2016 to study the response of drip fertigation intra row seeding of legume and planting geometry on soil health productivity and net return of summer maize. The experiment was laid in strip plot design with six vertical drip fertigation and intra row cowpea and three horizontal planting geometry. Raipur has a dry sub-humid to semi-dry climatic condition. The source of rainfall is south-western monsoon. It receives an average annual rainfall of $1400 \mathrm{~mm}$ The weekly maximum temperature raised up to $46^{\circ} \mathrm{C}$ during summer and minimum temperature reaches as low as to $6^{\circ} \mathrm{C}$ during winter season. Maize MM2562 hybrid was taken as test crop. The furrows were opened at $20 \mathrm{~cm}$ apart and 2 seeds per hill were dibbled in furrows to a depth of $4 \mathrm{~cm}$. After establishment of crop at 10 days of emergence, thinning was done by leaving one seedling per spot to maintain required plant density as per treatment. The come up irrigation was given just after planting. Irrigation treatments were imposed from 10 days after planting (DAP). Irrigation was scheduled according to the treatment. Five plants were selected at random and tagged these plants were used to record the growth, yield attributes and yield. The data pertaining to the experiment were subjected to statistical analysis suggested by Gomez and Gomez (1984).

\section{Results and Discussion}

\section{Irrigation water applied}

Water was applied as per the predefined treatments. Value of irrigation water applied was significantly highest $(1026 \mathrm{~mm})$ in furrow irrigation with $100 \% \mathrm{RDF}$ and cowpea over rest of the treatments but at par with furrow irrigation with $100 \mathrm{RDF}(1010 \mathrm{~mm})$. All the drip fertigation treatments were statistically similar.

These treatment utilized 644-675 mm irrigation water which was nearly half to that of traditional furrow/ flood irrigation. It indicates that maize area can be doubled adopting drip fertigation over furrow/ flood irrigation with same quantity of irrigation water and additive advantage of 134-140\% higher grain yield. Reduction in water consumption due to drip method of irrigation over the surface method of irrigation varies from 30 to 70 percent and productivity gain in the range of 20 to 90 per cent for different crops (Anitta Fanish et al., 2011). A properly 
designed drip fertigation system delivers water and nutrient at a rate, duration and frequency, so as to maximize crop water and nutrient uptake, while minimizing leaching of nutrients and chemicals from the root of agricultural field (Gardenas et al., 2005) (Table 1).

\section{Rainfall}

During growing season of maize $45 \mathrm{~mm}$ rains were received. Irrigation water compensated with rainfall during rain events.

\section{Total water use}

Irrigation applied and rainfall received during crop growing season was taken in total water use. At harvest of rice and maize visual soil moisture status was nearly similar hence soil moisture contribution was not taken into account of water use. The furrow irrigation treatments used 1055-1071 mm water whereas this quantity in drip fertigation was $689-720$ $\mathrm{mm}$. No remarkable difference in total water use was found in different planting densities.

\section{Water use efficiency}

Significantly higher water use efficiency (WUE) was obtained in drip fertigation with $125 \%$ RDF and cowpea and closely followed by all drip fertigation treatments. Significantly lower values of WUE recorded in furrow irrigation over drip fertigation. The maximum WUE was $9.0 \mathrm{~kg} \mathrm{ha}^{-1}-\mathrm{mm}$ in drip fertigation with $125 \%$ RDF and cowpea. Amongst crop geometry, remarkably highest WUE $(7.96 \mathrm{~kg}$ $\mathrm{ha}^{-1}-\mathrm{mm}$ ) was recorded in $60 \times 20 \mathrm{~cm}$ spacing.

For production of one $\mathrm{kg}$ grain 1137-1207 litres water required in drip fertigation whereas these value for furrow irrigation were 2328-2463 litres. In narrow spacing significantly more water required for production of one $\mathrm{kg}$ grain of maize compare to wider spacing.

Table.1 Influenced by fertigation and intra row legume and crop geometry on water use and water use efficiency of summer maize

\begin{tabular}{|c|c|c|c|c|c|}
\hline Treatments & $\begin{array}{l}\text { Irrigation } \\
\text { applied } \\
\text { (mm) }\end{array}$ & $\begin{array}{c}\text { Rainfall } \\
(\mathrm{mm})\end{array}$ & $\begin{array}{c}\text { Total } \\
\text { water use } \\
(\mathbf{m m})\end{array}$ & $\begin{array}{c}\text { Water use } \\
\text { efficiency } \\
\left(\mathrm{kg} \mathrm{ha}^{-1}-\mathrm{mm}\right)\end{array}$ & $\begin{array}{l}\text { Water use for } \\
\text { production of } \\
\text { maize (litres } \mathbf{k g}^{-1} \text { ) }\end{array}$ \\
\hline \multicolumn{6}{|l|}{ Fertigation and intra row seeding } \\
\hline F1: Drip Ferti.100\% RDF & 644 & 45 & 689 & 8.57 & 1180 \\
\hline F2: Drip Ferti.125\% RDF & 675 & 45 & 720 & 8.50 & 1207 \\
\hline F3: Furrow irri.100\% RDF & 1010 & 45 & 1055 & 4.24 & 2463 \\
\hline F4: Drip Ferti. $100 \%$ RDF + cowpea & 659 & 45 & 704 & 8.74 & 1151 \\
\hline F5: Drip Ferti.125\% RDF + cowpea & 664 & 45 & 709 & 9.00 & 1137 \\
\hline $\begin{array}{l}\text { F6: Furrow irri. } 100 \% \text { RDF + } \\
\text { cowpea }\end{array}$ & 1026 & 45 & 1071 & 4.35 & 2328 \\
\hline SEm \pm & 11 & & 11 & 0.14 & 36 \\
\hline $\mathrm{CD}(\mathrm{P}=0.05)$ & 35 & & 35 & 0.43 & 115 \\
\hline \multicolumn{6}{|l|}{ Crop geometry } \\
\hline S30: $30 \mathrm{~cm} \times 20 \mathrm{~cm}$ & 785 & 45 & 830 & 6.45 & 1757 \\
\hline S45: $45 \mathrm{~cm} \times 20 \mathrm{~cm}$ & 779 & 45 & 824 & 7.30 & 1442 \\
\hline S60: $60 \mathrm{~cm} \times 20 \mathrm{~cm}$ & 776 & 45 & 821 & 7.96 & 1534 \\
\hline SEm+ & 6 & & 6 & 0.10 & 29 \\
\hline $\mathrm{CD}(\mathrm{P}=0.05)$ & NS & & NS & 0.38 & 114 \\
\hline Interaction (FxS) & NS & & NS & NS & NS \\
\hline
\end{tabular}


Table.2 Influenced by drip fertigation and intra row legume and crop geometry on cob length cob diameter and no of grains $\mathrm{cob}^{-1}$

\begin{tabular}{|l|}
\hline Treatments \\
\hline Fertigation and intra row seeding \\
\hline F1: Drip Ferti.100\% RDF \\
\hline F2: Drip Ferti.125\% RDF \\
\hline F3: Furrow irri.100\% RDF \\
\hline $\begin{array}{l}\text { F4: Drip Ferti. 100\% RDF + } \\
\text { cowpea }\end{array}$ \\
\hline $\begin{array}{l}\text { F5: Drip Ferti.125\% RDF + } \\
\text { cowpea }\end{array}$ \\
\hline $\begin{array}{l}\text { F6: Furrow irri. } 100 \% \text { RDF + } \\
\text { cowpea }\end{array}$ \\
\hline SEm \pm \\
\hline CD(P=0.05) \\
\hline Crop geometry \\
\hline S30: $30 \mathrm{~cm} \times 20 \mathrm{~cm}$ \\
\hline S45: $45 \mathrm{~cm} \times 20 \mathrm{~cm}$ \\
\hline S60: $60 \mathrm{~cm} \times 20 \mathrm{~cm}$ \\
\hline SEm \pm \\
\hline CD(P=0.05) \\
\hline Interaction $($ FxS $)$ \\
\hline
\end{tabular}

\begin{tabular}{|c|c|c|c|}
\hline $\begin{array}{c}\text { Cob length } \\
(\mathbf{c m})\end{array}$ & $\begin{array}{c}\text { Cob } \\
\text { daimeter } \\
(\mathbf{c m})\end{array}$ & $\begin{array}{c}\text { No of grains } \\
\text { cob }^{-1}\end{array}$ & $\begin{array}{c}100 \text { grain } \\
\text { weight }(\mathrm{g})\end{array}$ \\
\hline 14.53 & 13.96 & 429.13 & 25.79 \\
\hline 14.76 & 14.56 & 450.36 & 26.40 \\
\hline 14.00 & 12.92 & 387.66 & 24.04 \\
\hline 14.85 & 14.13 & 465.03 & 26.42 \\
\hline 15.25 & 14.49 & 473.29 & 26.36 \\
\hline & & & \\
\hline 13.91 & 13.30 & 420.66 & 24.31 \\
\hline 0.25 & 0.17 & 14.65 & 0.65 \\
\hline 0.78 & 0.55 & 46.15 & NS \\
\hline & & & \\
\hline 13.34 & 12.96 & 364.62 & 24.56 \\
\hline 14.86 & 14.32 & 467.86 & 25.93 \\
\hline 15.44 & 14.40 & 480.52 & 26.18 \\
\hline 0.34 & 0.29 & 18.42 & 0.55 \\
\hline 1.35 & 1.14 & 72.33 & NS \\
\hline NS & NS & NS & NS \\
\hline
\end{tabular}

Table.3 Influenced by fertigation and intra row legume and crop geometry on grain yield, stover yield and harvest index of summer maize

\begin{tabular}{|l|}
\multicolumn{2}{|c|}{ Treatments } \\
\hline Fertigation and intra row seeding \\
\hline F1: Drip Ferti.100\% RDF \\
\hline F2: Drip Ferti.125\% RDF \\
\hline F3: Furrow irri.100\% RDF \\
\hline F4: Drip Ferti. 100\% RDF + cowpea \\
\hline F5: Drip Ferti.125\% RDF + cowpea \\
\hline F6: Furrow irri. 100\% RDF + \\
cowpea \\
\hline SEm \pm \\
\hline CD(P=0.05) \\
\hline Crop geometry \\
\hline S30: $30 \mathrm{~cm} \times 20 \mathrm{~cm}$ \\
\hline S45: $45 \mathrm{~cm} \times 20 \mathrm{~cm}$ \\
\hline S60: $60 \mathrm{~cm} \times 20 \mathrm{~cm}$ \\
\hline SEm \pm \\
\hline CD(P=0.05) \\
\hline Interaction $($ F xS) \\
\hline
\end{tabular}

\begin{tabular}{|c|c|c|}
\hline $\begin{array}{c}\text { Grain yield } \\
\left(\mathbf{q} \mathbf{~ h a ~}^{-1}\right)\end{array}$ & $\begin{array}{c}\text { Stover yield } \\
\left(\mathbf{q} \mathbf{~ h a ~}^{-1}\right)\end{array}$ & $\begin{array}{c}\text { Harvest } \\
\text { Index }(\%)\end{array}$ \\
\hline 54.76 & 115.06 & 32.22 \\
\hline 56.92 & 124.24 & 31.26 \\
\hline 42.28 & 92.41 & 31.43 \\
\hline 57.21 & 128.72 & 30.89 \\
\hline 59.12 & 136.62 & 30.20 \\
\hline 44.11 & 96.24 & 31.61 \\
\hline 0.71 & 2.54 & 0.41 \\
\hline 2.23 & 8.00 & NS \\
\hline 46.69 & 107.64 & 30.65 \\
\hline 54.19 & 116.66 & 32.02 \\
\hline 56.33 & 122.35 & 31.14 \\
\hline 0.58 & 4.27 & 1.06 \\
\hline 2.30 & NS & NS \\
\hline S & NS & NS \\
\hline
\end{tabular}


Table.4 Interaction between fertigation \& intra row seeding and crop geometry on yield ( $\left.\mathrm{q} \mathrm{ha}^{-1}\right)$ of summer maize

\begin{tabular}{|l|c|c|c|c|}
\hline Fertigation and intra row seeding & \multicolumn{4}{|c|}{ Crop geometry } \\
\hline F1: Drip Ferti.100\% RDF & S30 & S45 & S60 & Mean \\
\hline F2: Drip Ferti.125\% RDF & 49.98 & 51.28 & 63.01 & 54.76 \\
\hline F3: Furrow irri.100\% RDF & 44.88 & 61.43 & 64.46 & 56.92 \\
\hline F4: Drip Ferti. 100\% RDF + cowpea & 34.91 & 54.31 & 37.63 & 42.28 \\
\hline F5: Drip Ferti.125\% RDF + cowpea & 52.65 & 55.94 & 63.04 & 57.21 \\
\hline F6: Furrow irri. 100\% RDF + cowpea & 54.93 & 52.97 & 69.44 & 59.12 \\
\hline Mean & 42.77 & 49.19 & 40.38 & 44.11 \\
\hline & 46.69 & 54.19 & 56.33 & \\
\hline Two horizontal strip means at the same level of vertical strip & 1.57 & 4.84 \\
\hline Two vertical strip means at the some lever of horizontal strip & 0.49 & 1.48 \\
\hline
\end{tabular}

\section{Grain yield and yield parameters}

Significantly higher grain yield $\left(59.12 \mathrm{q} \mathrm{ha}^{-1}\right)$ was recorded in F5 which was at per with F4 (57.21 q ha $\mathrm{q}^{-1}$ ) and F2 (56.92q ha $\mathrm{ha}^{-1}$ ) while superior over rest of the treatments. Drip fertigation certainly improved availability of nutrients in root zone for plant uptake leading to better development of plants and dry matter production. The improved dry matter production enhanced grain yield in drip fertigation treatments (Table 3 and 4).

Cowpea further improved nutrient availability by fixing atmospheric nitrogen in soil thereby crop biomass and yield of crop. Hence better availability of nutrients in F5 lead to more uptake and better growth and development of plants resulted in remarkably higher yield of summer maize. Growth and yield attributes followed the pattern of grain yield. Stover yield was significantly higher in F5 than other treatments but at par with F4. Harvest index computed from grain and stover yield didn't differ significantly.

Cob length cob diameter and no of grains $\mathrm{cob}^{-1}$ was recorded highest in drip fertigation $125 \%$ RDF and cowpea which was at par with drip fertigation $100 \%$ RDF and cowpea, drip fertigation $125 \% \mathrm{RDF}$ and drip fertigation $100 \%$ RDF Little variation in number of grains per cob was recorded indicating genetic characteristics of variety under test. Similar results were reported by Maske et al., (2015) and Sampathkumar et al., (2010) (Table 2).

Better availability of nutrients in drip fertigation treatments may be reasons for longer cob over flood irrigation and split application of fertilizers.

Drip fertigation $100 \% \mathrm{RDF}$ and cowpea recorded highest no of rows $\mathrm{cob}^{-1}$ which was found similar to all othe treatments except drip fertigation $100 \%$ RDF and furrow irrigation $100 \%$ RDF and cowpea. 100 grain weight was found to be non-significantly influenced by fertigation.

Planting geometry $60 \times 20 \mathrm{~cm}$ recorded the highest no of cobs plant ${ }^{-1}$ cob length and cob diameter which was found similar with $45 \mathrm{x}$ $20 \mathrm{~cm}$ and the lowest was observed in $30 \times 20$ $\mathrm{cm}$. Similar results were reported by Thavaprakash et al., (2009) no of grins per cob also recorded the same pattern as cob 
length and cob diameter and the findings were supported by Mahapatra (2008), Oktem and Oktem (2005).

\section{References}

Fanish, S. A., Muthukrishnan, P. and Manoharan, S. 2011. Drip fertigation in maize based intercropping system. Indian J. Agric. Res., 45 (3): 233-238.

Gardenas et al., 2005. Agrl Water Management, 74 (3): 219-242.

Gomez, K.A. and Gomez, A.A. 1984. Statistical procedures for agricultural research. A Willey-Inter Sci. Publication. John Willey \& Sons, New York.

Oktem A. Oktem A. 2005 Effect of nitrogen and intra row spaces on sweet corn (Zea mays Sachharata Sturt) ear characteristics. Indian Jornal of Plant Sciences. 4 (4): 361-364.

Raina J. N., Thakur B. C. and Verma M. L. 1999. Effect of drip irrigation and polythene mulch on yield, quality and water use efficiency of tomato. Indian J. Agric. Sciences.69 (6):430-433.

Sampathkumar. T. and Pandaian. B. J. 2010. Effects of fertigation frequencies and level on growth and yield of maize. Madras Agric. J., 97 (7-9): 245-248.

Thavaprakash N. Veleyudham K., 2009 Influence of Crop Geometry, Intercropping Systems and INM Practices on Productivity of Baby Corn (Zea mays L.) based Intercropping System Mysore J. Agric, Sci., 43(4): 686-695

Zhu, H., Lan, y., Lamb, M. and Butts C. 2007.Corn nutritional properties and yield with surface drip irrigation in topographically variable fields. Agricultural Engineering International: The CGIAR Ejournal. Manuscript LW 07005.9

\section{How to cite this article:}

Minu Mohan, A.L. Rathore and Jha, S.K. 2018. Response of Drip Fertigation, Intra Row Seeding of Legume and Planting Geometry on Water Use and Yield of Summer Maize. Int.J.Curr.Microbiol.App.Sci. 7(10): 737-742. doi: https://doi.org/10.20546/ijcmas.2018.710.081 